\title{
IGNORANCE IS NOT BLISS: RESPONSIBLE CORPORATE OFFICERS CONVICTED OF ENVIRONMENTAL CRIMES AND THE FEDERAL SENTENCING GUIDELINES
}

\author{
LISA ANN HARIG
}

[O]ne ... does not have to be bad to do bad when it comes to environmental crimes. The "black heart" requirement commonly associated with other criminal activity is not necessary to sustain a conviction. ${ }^{1}$

\section{INTRODUCTION}

Each of the last three decades has seen a representative white-collar crime capture public attention. In the 1960s, the media covered antitrust violations of the Electrical Equipment conspiracy that met secretly to fix prices. ${ }^{2}$ The focus in the 1970s was on corporate bribery and pohtical corruption. ${ }^{3}$ The crime of the 1980 s was insider trading. ${ }^{4}$

During the latter part of the 1980s and now into this decade, environmental crimes have become the focus of much media coverage and public attention. One result of this attention has been an increase in the nnmber of criminal suits brought against corporations and their officers for environmental violations. ${ }^{5}$ The number of such criminal prosecutions has increased steadily im both

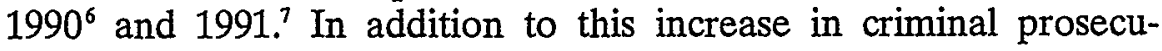

1. Judson W. Starr \& Thomas J. Kelly Jr., Environmental Crimes and the Sentencing Guidelines: The Time Has Come . . and It Is Hard Time, 20 Envtl. L. Rep. News \& Analysis (Envtl. L. Inst.) 10,096, 10,104 (1990).

2. John C. Coffee, Jr., Hush!: The Criminal Status of Confidential Information After McNally and Carpenter and the Enduring Problem of Overcriminalization, 26 AM. CRIM. L. REV. 121, 121 (1988).

3. Id.

4. Id.

5. Robert W. Adler \& Charles Lord, Environmental Crimes: Raising the Stakes, 59 GEO. WASH. L. REV. 781, 790 (1991).

6. EPA Continues to Exceed Previous Numbers in Civil, Criminal Cases, Penalty 
tions, the penalties involved (both fines and prison time) have been greatly enhanced by the Federal Sentencing Guidelines. ${ }^{8}$

Another response to the growing awareness of environmental crimes has been the expansion of the "responsible corporate officer doctrine" in the area of environmental law. Although this doctrine has been applied to public welfare statutes generally since the 1940s, it has only recently been widely applied to environmental statutes.

The responsible corporate officer doctrine was developed in a series of cases dealing with strict liability public welfare statutes. It evolved from the "responsible share doctrine," under which corporate officers were subject to strict liability for acts or omissions . of their companies in which they had a "responsible share," without regard to their direct participation in and knowledge of such acts or omissions. ${ }^{9}$

Assessments, 21 Env't Rep. (BNA) 1534 (Dec. 7, 1990) [hereinafter EPA Continues to Exceed Previous Numbers]. EPA Administrator William K. Reilly reported that the agency referred 65 criminal cases to the Justice Department in fiscal year 1990, an increase of five cases from fiscal year 1989. One hundred individuals and corporations were charged with criminal violations, 32 of which. were successfully prosecuted. Id.

7. Enforcement Actions at EPA Continue to Climb in Civil, Criminal Cases, Penalty Assessments, 22 Env't Rep. (BNA) 1832 (Nov. 29, 1991) [hereinafter Enforcement Actions at EPA]. Enforcement actions reached an all-time high in fiscal year 1991. One hundred four defendants, including both individuals and corporations, were charged with criminal violations that year. Of these, a total of 72 defendants (45 individuals and 27 organizations) were convicted and sentenced in the 48 successful cases. Id.

8. UNITEd States Sentencing Commission, Guidelines Manual (1992) [hereinafter GUIDELINES MANUAL], reprinted in 18 U.S.C.A. app. 4, at 64 (West Supp. 1992).

Fines increased dramatically during fiscal year 1990, due in part to one unusually large penalty. Fines imposed rose from $\$ 12.7$ million in fiscal year 1989 to $\$ 30$ million in fiscal year 1990. EPA Continues to Exceed Previous Numbers, supra note 6, at 1534. Fifteen million of the $\$ 30$ million 1990 total came from the Texas Eastern Gas Pipeline Co. It was the largest single settlement in EPA history. Id.

Sentences that included jail time were not unusual in fiscal 1990. Defendants were sentenced to a total of 745 months of imprisonment, resulting in 222 months of ordered incarceration after suspension of sentences. The Justice Department reported that more than half of the individuals convicted for environmental crines were sentenced to prison time. Id. About half of those sentenced were actually serving time in prison. The EPA reported that the sentences averaged more than one year. Id.

More than double the jail time was served in fiscal 1991 as in 1989. Further, crimmal judgments resulted in significantly longer sentences. Enforcement Actions at EPA, supra note 7, at 1832; see also Starr \& Kelly, supra note 1, at 10,096 ("One thing that can be said with certainty about these new rules is that criminal enforcement of the environmental laws has been vigorously and zealously augmented.").

9. United States v. Park, 421 U.S. 658, 673-74 (1975); United States v. Dotterweich, 320 U.S. 277, 284 (1943). 
Although the responsible corporate officer doctrine was first apphed in cases involving strict liability public welfare statutes, the doctrine was later apphed in cases involving public welfare statutes containing a scienter requirement. ${ }^{10}$ In the context of environmental crimes, this application has meant that, at the very least, the government has a greatly reduced burden of proof. ${ }^{11}$ Some cases even suggest that responsible corporate officers may be held strictly liable under statutes that, as written, require the government to prove mens rea. ${ }^{12}$

These developinents are particularly disturbing in hight of the severity of punishment inandated by the Federal Sentencing Guidehines. The Guidelines have substantially increased the probability that the convicted defendant will be sentenced to jail time and will actually serve time in jail..$^{13}$

This Note evaluates the responsible corporate officer doctrine and its relationship to the Sentencing Guidelines. Part I describes the developinent of the doctrine, from its origins in strict liability public welfare laws, to its expansion into environmental laws with a scienter requirement. Part II discusses the applicable parts of the Sentencing Guidelines and their relationship to the-responsible corporate officer doctrine. Part III suggests that while corporate officers should continue to be prosecuted for environmental violations, convictions under the responsible corporate officer doctrine should be grounds for downward departures im sentencing under the Guidelines. The responsible corporate officer doctrine should only be applied to crimes having a scienter requirement insofar as it advances the goals of the criminal justice system. ${ }^{14}$ Allowing downward departures froin the Sentencing Guidelines will best serve these interests, as well as ensure that the sentencing system will be perceived as fair and reasonable.

10. See infra text accompanying notes 40-74.

11. See infra text accompanying notes 40-74. .

12. See infra text accompanying notes $40-74$. In these cases, all the government need establish is that the defendant was a responsible corporate officer.

13. Judson W. Starr \& Thomas J. Kelly Jr., Environmental Crimes and the Sentencing Guidelines, NAT'L ENVTL. ENFORCEMENT J., June 1990, at 3, 8-12.

14. The goals of the criminal justice system include prevention, restraint, rehabilitation, deterrence, education, and retribution. WAYNE R. LAFAVE \& AUSTIN W. SCOTT, JR., CRIMINAL LAW $\S 1.5$, at 22-27 (2d ed. 1986). 


\section{THE RESPONSIBLE CORPORATE OFFICER DOCTRINE}

The responsible corporate officer doctrine developed in the context of misdemeanor prosecutions under public welfare statutes with no scienter requirement. From this narrow beginning, the doctrime has expanded to include felony violations under statutes with a mens rea element. As public concern for the environment has grown, so has the doctrine's coverage to include corporate officers who violate environmental statutes.

\section{A. Prosecution Under Strict Liability Public Welfare Statutes}

"The 'responsible corporate officer doctrine' evolved in a series of cases involving violations of strict habihty statutes."1s Strict hability for corporate actors was based on the theory that conventional mens rea requireinents ${ }^{16}$ are too heavy a burden on the justice system in cases involving public welfare statutes. The Supreme Court first addressed this burden in Shevlin-Carpenter Co. $v$. Minnesota ${ }^{17}$ and determined that due process is not violated by public welfare statutes lacking a scienter requirement. ${ }^{18}$ The Court stated that "public policy may require that in the prohibition or pumshment of particular acts it may be provided that he who shall do thein shall do them at his peril and will not be heard to plead in defense good faitl or ignorance." 19

In United States $v$. Balint ${ }^{20}$ the Court once again upheld the constitutionality of strict liability public welfare statutes. This time, the Court relied on Shevlin-Carpenter to reject the defendants' due process argument: "While the general rule at common law was that the scienter was a necessary element in the indictment and proof of every crime..., there has been a modification of this

15. Thruxtun Hare, Comment, Reluctant Soldiers: The Criminal Liability of Corporate Officers for Negligent Violations of the Clean Water Act, 138 U. PA. L. REv. 935, 967 (1990).

16. Generally, conventional mens rea "requires that the actor must be aware of the factors making his conduct criminal." Id. at 969.

17. 218 U.S. 57 (1910).

18. Id. at $67-70$. The defendant corporation was convicted of violating a statute that forbade the removal, without a valid permit, of timber from state lands. Id. at 62-63. The statute included incarceration as a possible punishment. Id. at 62 n.1.

19. Id. at 70 .

20. 258 U.S. 250 (1922). 
view in respect to prosecutions under statutes the purpose of which would be obstructed by such a requirement."21

Over twenty years later, in United States $v$. Dotterweich, ${ }^{2}$ the Court applied the public welfare exception to the scienter requirement to corporate officers and created the responsible share doctrine. In Dotterweich, the president and general manager of a pharmaceutical company had been convicted of violating the federal Food, Drug, and Cosmetic Act (FDCA) ${ }^{23}$ by shipping misbranded products. Although the shipment had been accidental, ${ }^{24}$ the Court nonetheless upheld the defendant's conviction. While acknowledging that a conviction without proof of any criminal intent on the part of the defendant may be harsh in some instances, the Court concluded that:

Balancing relative hardships, Congress has preferred to place it upon those who have at least the opportunity of informing themselves of the existence of conditions imposed for the protection of consumers before sharing in illicit commerce, rather than to throw the hazard on the innocent public who are wholly helpless. ${ }^{26}$

The Court also discussed the concept of an actor's "responsible share." The Court held that "[t]he offense is committed . . . by all who do have such a responsible share in the furtherance of the transaction which the statute outlaws",27 and that the trier of fact must determine whether the person's conduct amounts to a "responsible share."28

Some authors have commented that the concept of responsible share contains an implicit allegation of neghigent conduct; ${ }^{29}$ as

21. Id. at $251-52$.

22. 320 U.S. 277 (1943).

23. 21 U.S.C. $\$ \S 301-393$ (1988). Section 331(a) prohibits "[t]he introduction or delivery for introduction into interstate commerce of any ... drug . . . that is adulterated or misbranded." At the time the case was adjudicated, § 333(a) made it a misdemeanor for any "person" to violate a provision of $\$ 331.21$ U.S.C. $\S 333$ (a) (1940). Strict liability for a felony violation of a public welfare statute was establislied by United States v. Freed, 401 U.S. 601, 607-10 (1971).

24. The company did not manufacture the drugs, but merely repackaged thein with their own label without knowledge of their alteration. Dotterweich, 320 U.S. at 278.

25. Id. at 284 .

26. Id. at 285 .

27. Id. at 284 .

28. Id.

29. See, e.g., Norman Abrams, Criminal Liability of Corporate Officers for Strict 
one author put it, "[t]he word 'responsible' itself reflects some notion of culpability." ${ }^{30}$ In Dotterweich, this neghigence arose from the fact that "the officer was in a position of control and, since a violation occurred, the officer presumably failed in his duty to prevent that violation." ${ }^{31}$

The responsible corporate officer doctrine evolved from the responsible sliare doctrine more than thirty years later in United States v. Park..$^{32}$ Like Dotterweich, Park involved a violation of the FDCA. ${ }^{33}$ In this case, the president of Acme Markets, a national retail food cham, was convicted of allowing food received via interstate commerce and lield for sale im a warehouse, to be stored in a building accessible to, and contaminated by, rodents. ${ }^{34}$ The Court narrowed somewhat the reach of the responsible share doctrine: It acknowledged that responsible share included "some measure of blameworthiness." ${ }^{35}$ Nevertheless, it stated that the government need only prove that the defendant lad, "by reason of his position in the corporation, responsibility and authority either to prevent in the first instance, or promptly to correct, the violation complained of, and that lie failed to do so." ${ }^{36}$ The Court also held that while the defendant can claim that he was powerless to prevent or correct the violation, the defendant carries the burden of producing evidence of his own powerlessness. ${ }^{37}$

Under Park, corporate officers lave been held criminally liable for environmental crimes even if they committed no overt act and had no intent or even knowledge of blameworthiness. ${ }^{38}$

Liability Offenses-A Comment on Dotterweich and Park, 28 UCLA L. REv. 463, 466 (1981); Hare, supra note 15, at 972.

30. Abrams, supra note 29 , at 465.

31. Hare, supra note 15 , at 972 .

32. 421 U.S. 658 (1975).

33. 21 U.S.C. $\$ \S 301-393$ (1988). Section $331(k)$ prohibits:

The alteration, mutilation, destruction, obliteration, or removal of the whole or any part of the labeling of, or the doing of any other act with respect to, a food, drug, device, or cosmetic, if such act is done while such article is held for sale (whether or not the first sale) after shipment in interstate commerce and results in such article being adulterated or misbranded.

34. Park, 421 U.S. at 660 . An FDA Consumer Safety officer who had inspected the building found mouse pellets and a hole chewed in one of the boxes. Id. at 662 n.4.

35. Under Park, corporate officers may not be held criminally liable merely on the basis of the title of their positions. Instead, accountability is to be based on the responsibilities and authority of their positions. Id. at 673 .

36. Id. at $673-74$.

37. Id. at 673 .

38. A more recent case suggests that this elimination of both the actus reus as well 
Their omissions need not even have amounted to negligence..$^{39}$ The government need only prove that the corporate officer was in a position to prevent or correct the violation and failed to do so.

\section{B. Prosecution Under Public Welfare Statutes with a Scienter Requirement}

Regardless of how they have interpreted "knowledge," courts have minimized the government's burden of proving it in cases involving public welfare statutes containing a scienter requirement. The responsible corporate officer doctrine has extended beyond the realm of cases involving strict liability public welfare statutes to apply to these cases as well. Knowledge will often be imputed from einployees of the corporation to its responsible officers. At the very least, the trier of fact may infer knowledge from the circumstances surrounding the case.

In United States v. International Minerals \& Chemical Corp.,$^{40}$ the Supreine Court held that the word "knowingly" in the statute at issue pertained to knowledge of the facts, not to knowledge of the regulation itself or to the violation of the regulation. ${ }^{41}$ Thus, the corporate officer only had to know that the shipment was made; he did not have to be aware that a regulation governed the shipinent or that such regulation had been violated. The Court stated that when dangerous products are involved, "the probability of regulation is so great that anyone who is aware that he is in possession of them or dealing with them must be presumed to be aware of the regulation." ${ }^{\text {"2 }}$ Thus, knowledge of the regulation may be imputed to the defendant through his knowledge of the facts - surrounding the violation. In his dissent, Justice Stewart stated that

as the mens rea requirement will be reserved for cases involving "conduct that a reasonable person should know is subject to stringent public regulation and may seriously threaten the community's health or safety." Liparota v. United States, 471 U.S. 419, 433 (1985).

39. Ann Hopkins, Comment, Mens Rea and the Right to Trial by Jury, 76 CAL. L. REV. 391, 411 (1988).

40. 402 U.S. 558 (1971). The defendant in International Minerals was charged with shipping sulfuric and hydrofluosilicic acids in interstate commerce without indicating on the shipping papers that they were classified as Corrosive Liquids, in violation of 18 U.S.C. $\S 834(\mathrm{a})$. 18 U.S.C. $\S 834(\mathrm{f})$ state that whoever "knowingly violates any such regulation" shall be fined or imprisoned. Law of Sept. 6, 1960, ch. 645, $\$ 834(f)$, 74 Stat. 810 (repealed 1979).

41. 402 U.S. at 563.

42. Id. at 565 . 
the majority's holding meant that a person who had never heard of the regulation might make a single shipment in his lifetime and be guilty of a criminal offense punishable by a year in prison. ${ }^{43}$

In the landmark case of United States v. Johnson \& Towers, Inc., ${ }^{44}$ the United States Court of Appeals for the Third Circuit held that the Resource Conservation and Recovery Act (RCRA) ${ }^{45}$ requires knowledge both of the regulation and of the violation. ${ }^{46}$ The defendants im this case were charged with pumping hazardous wastes into a trench that flowed into a creek without a permit. ${ }^{47}$ Although RCRA required the defendants to have a permit for such activity, the defendants neither apphed for nor were issued a permit. ${ }^{48}$ The court expanded the traditional view that only owners or operators of the facility could be held responsible if they "knew or should have known" that their company had not complied with RCRA's permit requirement. ${ }^{49}$ The court found that in this case, the defendants, mid-level managers who had supervised and directed the treatment, storage, and disposal of hazardous wastes, could be subject to criminal prosecution if it were shown that they knew or should have known of the company's failure to comply with the permit requirement. ${ }^{50}$

Although the Third Circuit required knowledge both of the regulation and of the violation, the outcome in Johnson \& Towers

43. Id. at 569 (Stewart, J., dissenting).

44. 741 F.2d 662 (3d Cir. 1984), cert. denied, 469 U.S. 1208 (1985).

45. 42 U.S.C. $\$ \S 6901-6992(\mathrm{k})$ (1988). Prior to $1984, \S 6928(\mathrm{~d})$ provided:

Any person who-

(2) knowingly treats, stores, or disposes of any hazardous waste identified or listed under this subchapter either-

(A) without having obtained a permit under section 6925 of this title ... or such permit ...

(B) in knowing violation of any material condition or requirement of

shall, upon conviction, be subject to a fine of not more than $\$ 25,000 \ldots$ for each day of violation, or to imprisonment not to exceed one year...., or both ....

42 U.S.C. $\S 6928$ (d) (1982). In 1984, Congress amended the wording of this provision slightly, and increased the penalty to $\$ 50,000$ per day of violation or two years of imprisonment or both. Hazardous and Solid Waste Amendments Act of 1984, Pub. L. No. 98-616, § 232(a)(3), 98 Stat. 3221, 3256-57.

46. 741 F.2d at 669.

47. Id. at 664 .

48. Id.; see also RCRA, 42 U.S.C. $\$ 6925$ (1982).

49. 741 F.2d at 664.

50. Id. at 664-65. 
is essentially the same as in International Minerals. The Johnson \& Towers court stated that any knowledge, including knowledge of the permit requirement, "Inay be inferred by the jury as to those individuals who hold the requisite responsible positions with the corporate defendant."s1 Thus the burden on the prosecution under Johnson \& Towers is not significantly greater than it is under International Minerals.

The Third Circuit has been criticized for its approach in Johnson \& Towers. Most circuit courts have expressly or impliedly declined to adopt its reasoning, and have instead made the prosecution's burden of proof lighter. ${ }^{52}$ The Eleventh Circuit, for instance, held in United States v. Hayes International Corp. ${ }^{53}$ that a conviction under RCRA's permit provision ${ }^{54}$ requires only that the defendant knew there was no permit for the disposal site, and that the waste disposed of was a mixture of paint and a solvent. ${ }^{55}$ The defendant cannot claim in defense that lie did not know that sucli waste was hazardous within the meaning of the regulations, or that he did not know a permit was required. ${ }^{56}$

In contrast, the Ninth Circuit held in United States v. Hoflin ${ }^{57}$ that knowledge that a disposal permit had not been obtained was not required for a conviction for improper disposal under RCRA. The defendant in Hoflin was convicted of violating the same RCRA provision as had been violated in Johnson \& Towers. $^{58}$ The court based its reasoning on congressional intent: "Had Congress intended knowledge of the lack of a permit to be an eleinent under subsection (A) it easily could have said so. It specifically inserted a knowledge element in subsection (B), and it did so

51. Id. at 670.

52. See, e.g., United States v. Dean, 969 F.2d 187 (6th Cir. 1992); United States v. Baytank (Houston), Inc., 934 F.2d 599 (5th Cir. 1991); United States v. Hoflin, 880 F.2d 1033 (9th Cir. 1989), cert. denied, 493 U.S. 1083 (1990). These cases are discussed infra at notes 57-60, 64-65 and accompanying text.

53. 786 F.2d 1499 (11th Cir. 1986).

54. 42 U.S.C. $\S 6928(d)(1)(1988)$.

55. 786 F.2d at 1505 .

56. Id. at 1503. In reaching this decision, the court concluded that Liparota v. United States, 471 U.S. 419, 433 (1985), did not control in cases involving RCRA violations. Id. at 1503; see supra note 38 .

The Ninth Circuit recently followed Hayes International in holding that RCRA's permit provision "requires proof that the defendant knew the facility lacked a permit." United States v. Speach, 968 F.2d 795, 796 (9th Cir. 1992).

57. 880 F.2d 1033, 1038 (9th Cir. 1989), cert. denied, 493 U.S. 1083 (1990).

58. Id. at 1034; see supra note 45 . 
notwithstanding the 'knowingly' modifier which introduces subsection (2). ${ }^{.59}$ The court also cited International Minerals in approval of its presumption that anyone dealing in hazardous materials has knowledge of the regulations governing them..$^{60}$

In United States $v$. Dee, ${ }^{61}$ the Fourth Circuit held that the defendants "knowingly" violated criminal provisions of RCRA even though they were unaware that violation of RCRA was a crime, or that RCRA regulations existed listing and identifying chemical wastes as hazardous wastes. ${ }^{62}$ The evidence presented at trial strongly indicated that the defendants were aware they were dealing with hazardous chemicals, and that the chemicals were "wastes" within the meaning of RCRA. ${ }^{63}$

The next year, the Fifth Circuit followed Dee and Hoflin in deciding United States $v$. Baytank (Houston), Inc. ${ }^{64}$ The court stated that "'knowingly' means no inore than that the defendant knows factually what he is doing ... and it is not required that he know that there is a regulation which says what he is storing is hazardous under the RCRA."65

In contrast to the preceding cases, in United States $v$. MacDonald \& Watson Waste Oil Co. ${ }^{66}$ the First Circuit held that knowledge or belief that illegal slipments of the type alleged had previously occurred was not enough to satisfy the scienter requirement of the statute at issue. ${ }^{67}$ The court stated, lowever, that "knowledge may be inferred from circumstantial evidence, including position and responsibility of defendants such as corporate officers, as well as information provided to those defendants on prior occasions." ${ }^{\text {as }}$ The court continued:

59. 880 F.2d at 1038 .

60. Id. The Sixth Circuit, agreeing with the reasoning in Hoflin, recently held that "[t]he 'knowingly' which begins [RCRA] § 6928(d)(2) cannot be read as extending to the subsections without rendering nugatory the word 'knowing' contained in subsections $6928(d)(2)(B)$ and (C) . . . [Subsection 6928(d)(2)(A)] does not require that the person charged have known that a permit was required ...." United States v. Dean, 969 F.2d 187, 191 (6th Cir. 1992).

61. 912 F.2d 741 (4th Cir. 1990), cert. denied, 111 S. Ct. 1307 (1991).

62. Id. at 745 .

63. Id. at $745-46$.

64. 934 F.2d 599 (5th Cir. 1991).

65. Id. at 613 .

66. 933 F.2d 35 (1st Cir. 1991).

67. Id. at 51 .

68. Id. at 55 . 
Simply because a responsible corporate officer believed that on a prior occasion illegal transportation occurred, he did not necessarily possess knowledge of the violation charged. In a crime having knowledge as an express element, a mere showing of official responsibility under Dotterweich and Park is not an adequate substitute for direct or circumstantial proof of knowledge. ${ }^{69}$

C. Expanding the Responsible Corporate Officer Doctrine: United States v. Brittain

The Court of Appeals for the Tenth Circuit took an expansive position in its consideration of the responsible corporate officer doctrine. United States v. Brittain ${ }^{70}$ involved the prosecution under the Clean Water Act of the director of public utilities for the city of Enid, Oklahoma. The defendant was convicted of "willfully or neghigently" discharging pollutants into navigable waters in noncompliance with the issued National Pollutant Discliarge Elimination Systein (NPDES) permit."

The defendant appealed his conviction on the theory that he was not a criminally liable "person" as defined under the statute because he was neither a permittee nor a responsible corporate officer of the discliarging permittee. ${ }^{72}$ The court flatly rejected this argument and held that the defendant was a person subject to criminal liability under the Act. The court interpreted the specific addition of responsible corporate officers to the Act as an expansion of liabihty, reasoning that Congress added responsible corpo-

69. Id.

70. 931 F.2d 1413 (10th Cir. 1991).

71. Id. at 1418. At the time of the indictment, the applicable section of the Clean Water Act provided, in part:

(1) Any person who willfully or negligently violates section 1311 ["the discharge of any pollutant by any person shall be unlawful" except as in compliance with the law $\ldots$ of this title, or any permit condition or himitation implementing any of such sections in a permit issued under section 1342 [NPDES permit] of this title by the Administrator .... shall be punished ....

(3) For the purposes of this subsection, the term "person" shall mean, in addition to the definition contained in section 1362(5) of this title [" 'person' means an individual, corporation, partnership, association, State, municipality, commission, or political subdivision of a State, or any interstate body."], any responsible corporate officer.

33 U.S.C. \& 1319 (c) (1982).

72. Brittain, 931 F.2d at 1419. 
rate officers to the list of criminally hable persons in keeping with the public welfare nature of the Clean Water Act. ${ }^{73}$ The court further explained that "[u]nder this interpretation, a 'responsible corporate officer,' to be held criminally liable, would not have to 'willfully or negligently' cause a permit violation. Instead, the willfulness or negligence of the actor would be imputed to him by virtue of his position of responsibility." ${ }^{37}$

The Brittain court borrowed the responsible corporate officer doctrine from strict hability public welfare statutes and applied it to public welfare statutes with a scienter requirement. Whereas other courts liave made the government's burden of proof fairly liglit by allowing knowledge to be inferred from circumstantial evidence, including the fact that the defendant was a responsible corporate officer, the Tenth Circuit has effectively read the scienter requirement out of public welfare statutes prosecutions when responsible corporate officers are involved.

Brittain represents the broadest application yet of the responsible corporate officer doctrine in the environmental law setting. Growing concern for environmental crimes has prompted this expansion; moreover, this concern is one reason why the United States Sentencing Commission has increased the severity of sentencing for environmental crimes.

\section{The Federal Sentencing Guidelines}

The application of the responsible corporate officer doctrine to environmental violators is troubling when viewed in connection with the liarsh consequences of the Federal Sentencing Guidelines. ${ }^{75}$ Not only lias the responsible corporate officer doctrine lowered the burden of proof for environmental crimes requiring the defendant's knowledge, but the Guidelines have substantially mcreased the probability that the convicted defendant will be sentenced to jail time, and will actually serve time in jail. ${ }^{76}$

73. Id.

74. Id.

75. See GUIDELINES MANUAL, supra note 8 .

76. See Starr \& Kelly, supra note 13 , at 8-12. 


\section{A. The Mechanics of the Guidelines}

Prior to 1987, defendants convicted of federal environmental crimes were sentenced according to the criminal penalty provisions of the statutes they violated." Since 1987, defendants have been subject to sentences imposed under the Federal Sentencing Guidelines. ${ }^{78}$

The Guidelines include specific provisions for sentencing environmental violators ${ }^{79}$ and put environmental crimes on a par with other white-collar crimes. ${ }^{80}$ Some commentators have suggested that in terms of punishment, the new rules move environmental crimes closer to serious crimes of violence. ${ }^{81}$ The Guidelines are especially hard on environmental violators because the United States Sentencing Commission was "aware that Congress has expressed views in favor of tougher penalties for white-collar offenses .... Environmental offenses can-and quite often do-pose a threat to society that far outweighs their number."82 Therefore, judges have been forced to take environmental crimes much more seriously than they have in the past. ${ }^{83}$

Under the Guidelines, environmental offenses are divided into four categories:

(1) knowing endangerment of human life;

(2) offenses involving hazardous or toxic substances;

77. See Adler \& Lord, supra note 5, at 797 app. D.

78. See Guidelines MANUAL, supra note 8. The United States Sentencing Commission is an eight-member panel established by the Comprehensive Crime Control Act of 1984, 28 U.S.C. $\$ \S 991-998$ (1988). In 1987, the Commission published the Federal Sentencing Guidelines. Two important goals of the Guidehines are: first, "ensur[ing] proportionality in sentencing among defendants found guilty of similar conduct," and second, "remov[ing] the uncertainty that previously characterized the sentencing process." Starr \& Kelly, supra note 1, at 10,096-97. The Supreme Court upheld the constitutionality of the act creating the Sentencing Commission and the Guidelines in Mistretta v. United States, 488 U.S. 361, 412 (1989).

The Criminal Fine Improventents Act of 1987 also affected the sentences given to environmental violators, but it is not within the scope of this Note. Pub. L. No. 100-185, 101 Stat. 1279 (codified in scattered sections of 18 U.S.C.). For a discussion of the Act, see Adler \& Lord, supra note 5, at 799-800.

79. GUIDELINES MANUAL, supra note $8, \S \S 2 \mathrm{Q} 1.1-2 \mathrm{Q} 2.1$.

80. Starr \& Kelly, supra note 1 , at 10,096 .

81. Id.

82. Id. at 10,097 n.6 (quoting Judge William A. Wilkins, Chairman, U.S. Sentencing Commission, Address at the National Conference on Local and State Enforcement of the Environmental Laws (Mar. 30, 1989)).

83. Id. at 10,096 . 
(3) offenses involving other pollutants; and

(4) offenses against conservation and wildlife. ${ }^{84}$

The Guidelines have changed the way that judges may impose sentences. ${ }^{85}$ The traditional flexibility judges have enjoyed in sentencing has been replaced with rigid guidelines removing virtually all discretion for sentencing certain crimes, including environmental offenses. ${ }^{86}$ Each offense category has a base penalty level for knowing violations of environmental statutes. That penalty level may increase if, for example, pollutants are released into the environment, if the violation is ongoing or continuous, or if the defendant has a criminal history. ${ }^{87}$ The penalty level may decrease if the violation resulted from neghigence, or involved only recordkeeping or reporting. ${ }^{88}$ Prior to the Guidelines, probation in lieu of jail time and suspension of prison sentences were commonplace im the sentencing of environmental violators. ${ }^{89}$ However, judges are no longer free to utilize such sentencing practices. A solely probationary term (i.e., one without any time in jail) is available only to defendants convicted of offenses with penalty levels of 1 to 6.90 Defendants convicted of crimes that carry penalty levels of 7 to 10 may be eligible for probation with a condition of intermittent or community incarceration or home detention." Furthermore, the new guidelines do not permit suspended sentences. ${ }^{92}$ Consequently, "[j]ail time will become the norm rather than the exception under the new rules."

Consider, for instance, the defendant in Hoflin ${ }^{94}$ who received two years of probation for his RCRA conviction. ${ }^{95} \mathrm{Had}$ the defendant's violations occurred after November 1, 1987 (the effective date of the Sentencing Guidelines), his sentence would

84. Adler \& Lord, supra note 5, at 798. This Note does not include a discussion of conservation and wildlife offenses.

85. For a more detailed discussion of sentencing under the Federal Sentencing Guidelines, see Starr \& Kelly, supra note 13, at 4-6.

86. For example, sentences are now determinate, and parole has been abolished. Id. at 3.

87. Adler \& Lord, supra note 5, at 798.

88. GUIDELINES MANUAL, supra note $8, \S 2 \mathrm{Q} 1.1$ to 3 .

89. Adler \& Lord, supra note 5, at 798-99.

90. GUIDELINES MANUAL, supra note $8, \S \S 5 \mathrm{~A}, 5 \mathrm{~B} 1.1(\mathrm{a})$.

91. Id.

92. Adler \& Lord, supra note 5, at 799.

93. Starr \& Kelly, supra note 1 , at 10,097 .

94. See supra notes 57-60 and accompanying text.

95. Starr \& Kelly, supra note 13, at 7. 
have been significantly higher. His violations would have resulted in an offense level of $16{ }^{96}$ for a sentencing range of twenty-one to twenty-seven months in prison. ${ }^{97}$ Furthermore, the sentencing judge would not have been permitted to suspend the sentence in favor of probation at that offense level.

\section{B. Departures from the Guidelines}

In addition to setting a base offense level for each of the categories of environmental violations, the Sentencing Guidelines also allow for departures, under limited circumstances, from these base levels. ${ }^{98}$ According to its policy statement, the Guidelines permit a court to impose a sentence outside of the base level sentencing range "if the court finds 'that there exists an aggravating or mitigating circumstance of a kind, or to a degree, not adequately taken into consideration by the Sentencing Commission in formulating the guidelines that should result in a sentence different from that described." "999

One of the enumerated grounds for departure is public welfare. ${ }^{100}$ The policy statement reads: "If national security, public health, or safety was significantly endangered, the court may increase the sentence above the guideline range to reflect the nature and circumstances of the offense." 101 This possible increase in sentencing has special applicability to environmental defendants. Because environmental statutes are considered public welfare laws, violations potentially endanger public health or safety. ${ }^{102}$ Thus,

96. Id. Hoflin's base offense level for mishandling of a hazardous substance would have been 8 under the Guidelines. GUIDELINES MANUAL, supra note $8, \S 2 \mathrm{Q} 1.2$. He would have received a four-level upward adjustment for discharge, release, or emission of a hazardous substance, and an additional four-level upward adjustment for disposing of paint wastes without a permit. Id. $\S \S 2 \mathrm{Q} 1.2(\mathrm{~b})(1)(\mathrm{B}), 2 \mathrm{Q} 1.2(\mathrm{~b})(4)$.

97. GUIDELINES MANUAL, supra note 8, at 280 .

98. Id. §§ $5 \mathrm{~K} 1.1-5 \mathrm{~K} 2.16$.

99. Id. $\S 5 \mathrm{~K} 2.0$ (quoting 18 U.S.C. $\S 3553(\mathrm{~b})$ (1988)). The policy statement continues:

Circumstances that may warrant departure from the guidelines pursuant to this provision cannot, by their very nature, be comprehensively listed and analyzed in advance. The controlling decision as to whether and to what extent departure is warranted can only be made by the courts .... [T]lie court may depart from the guidelines, even though the reason for departure is taken into consideration in the guidelines ... if the court determines that, in light of unusual Id. circumstances, the guideline level attached to that factor is inadequate.

100. Id. § $5 \mathrm{~K} 2.14$.

101. Id. (emphasis added).

102. See, e.g., Umited States v. Hayes International Corp., 786 F.2d 1499, 1503 (11th 
the sentences of responsible corporate officers for environmental violations can be increased if the violations are believed by the sentencing judge to have been of a degree of seriousness not fully taken into consideration by the Sentencing Commission.

The Guidelines that deal with environmental offenses specifically state that they apply to knowing violations. ${ }^{103}$ Some of the accompanying Application Notes state, however, that neghigent conduct may warrant a downward departure in sentencing. ${ }^{104}$ Accordingly, a sentencing judge can give a sentence shorter than that required by the Guidelines if he believes that the defendant's conduct was merely neghigent.

\section{CONVICTION UNDER THE RESPONSIBLE CORPORATE OFFICER DOCTRINE AS GROUNDS FOR DOWNWARD DEPARTURE FROM THE SENTENCING GUIDELINES}

Coinciding with the increased penalties for environmental violations is the expansion of the responsible corporate officer doctrine in the area of environmental law. This expansion is most likely the result of at least two phenomena. First, the dramatic increase in the number of prosecutions ${ }^{105}$ of environmental crimes has brought the issue of corporate officer criminal liability in the environmental setting before the courts in large numbers. The complete importation of the responsible corporate officer doctrine into environmental prosecutions reflects the perceived importance of these statutes to the public health and welfare.

Second, public awareness about the importance of preserving the environment has grown. Congress has responded by criminalizing violations of environmental regulations. ${ }^{106}$ The United States Sentencing Commission, in turn, has responded by enhancing the penalties for environmental crimes significantly. ${ }^{107}$

Cir. 1986) (stating that RCRA is "undeniably a public welfare statute").

103. GUIDELINES MANUAL, supra note 8, § 2Q1.1 (entitled "Knowing Endangerment Resulting From Mishandling Hazardous or Toxic Substances, Pesticides or Other Pollutants"); id. § 2 Q1.2 applic. n.4 (noting that "this section assumes knowing conduct"); id. $\$$ 2Q1.3 applic. n.3 (noting that "[t]he specific offense charácteristics in this section assume knowing conduct").

104. Id. § 201.2 applic. n.4; id. § $2 \mathrm{Q} 1.3$ applic. n.3.

105. See supra notes 6-8.

106. Judson W. Starr, Countering Environmental Crimes, 13 B.C. ENVTL. AFF. L. REV. 379, 379-80 (1986).

107. See supra notes $79-83$ and accompanying text. 
This Note contends that the Sentencing Commission did not adequately take the responsible corporate officer doctrine into account when it drafted the Guidelines. This doctrine should be considered in sentencing decisions as a basis for downward departures for two reasons: First, while the Guidehines assume knowing conduct, the responsible corporate officer doctrine allows the trier of fact to impute knowledge to the defendant. Thus, corporate officers convicted under this doctrine will be sentenced the same way as an actor with actual knowledge. Second, longer sentences that are perceived as noncommensurate with the crimes may discourage prosecution and conviction of environmental criminals.

First, the Guidelines that apply to environmental violations state that they "assume knowing conduct."108 They also state that a judge may consider whether the conduct was merely negligent, and adjust the sentence accordingly. ${ }^{109}$ The Guidelimes do not mention either responsible corporate officers or strict liability. However, because the responsible corporate officer doctrine is central to criminal environmental prosecutions, it is worthy of consideration at the sentencing level. In fact, the responsible corporate officer doctrine is so pervasive in such prosecutions that conviction under the doctrine should be listed specifically as a ground for a downward departure under the Guidelines.

No court has ever explicitly stated that the responsible corporate officer doctrine is a neghigence standard, and no court is likely ever to do so. The responsible corporate officer doctrine is viewed as a reduction in the burden of proof that the government is required to meet. It is not labelled a negligence standard, and responsible corporate officers would not be eligible for downward departures from Guidelines sentencing ranges on this ground. ${ }^{10}$ However, at least one commentator has argued that most courts are likely to agree witl Justice Stewart's dissent in United States $v$. Park that the majority did in fact adopt a negligence standard, despite its never exphicitly inentioning neghigence. ${ }^{111}$ Then, because the Guidelines allow for downward departures for negli-

108. See supra note 103 and accompanying text.

109. See supra note 104 and accompanying text.

110. Although the concept of "responsible share" as defined by the Dotterweich court, discussed supra at notes 22-31 and accompanying text, may imply an allegation of negligence, Park held that the defendant's omission did not even have to amount to negligence; see supra notes 38-39 and accompanying text.

111. Abrams, supra note 29 , at $469-70$. 
gence, they should also allow for downward departures for convictions under the responsible corporate officer doctrine-the rationale in both cases being that defendants who lacked knowledge of crimes committed should not be punished as severely as those who possessed knowledge.

There is evidence that Congress wanted the Sentencing Commission to consider factors that are directly related to the responsible corporate officer doctrine. The Commission has been criticized for failing to consider the personal characteristics of the offender in promulgating the Sentencing Guidelines. ${ }^{112}$ One commentator has noted that the defendant's role in the offense and his dependence upon criminal activity for a livelihood, among other factors, were ignored by the Commission, despite Congress's reconimendation that they be considered. ${ }^{113}$ Under the responsible corporate officer doctrine, consideration of the defendant's role is especially important. The prosecution is not required to prove actual knowledge in these cases; knowledge may be imputed to the defendant or inferred from the existing circumstances. ${ }^{114}$ Often, the responsible corporate officer will liave played no role in the offense other than liaving failed to prevent it. A downward departure would better reflect the actual role of the responsible corporate officer in the offense.

Second, longer sentences may discourage prosecution and conviction of environmental criminals. For the criminal justice system to work, punishment must be perceived by the public as fair and commensurate with the severity of the offense. ${ }^{115}$ Convicting responsible corporate officers of crimes of which they had no actual knowledge may be a reasonable approach to dealing witl enviroumental violations; but sentencing them to long prison terins is neither just, nor commensurate witl their offenses.

In addition, the possibility of excessive prison terms may actually discourage conviction of corporate officers. ${ }^{116}$ One of the

112. Charles J. Ogletree, Jr., The Death of Discretion? Reflections on the Federal Sentencing Guidelines, 101 HARV. L. REV. 1938, 1953 (1988).

113. Id.

114. See supra notes 40-74 and accompanying text; see also United States v. Brittain, 931 F.2d 1413, 1419 (10th Cir. 1991) (stating that responsible corporate officers can be held strictly liable for offenses of their corporations).

115. See Joann L. Miller et al., Felony Punishments: A Factorial Survey of Perceived Justice in Criminal Sentencing, 82 J. CRIM. L. \& CRIMINOLOGY 396, 396 (1991).

116. See, e.g., U.S. Department of Justice Principles of Federal Prosecution, 27 Crim. L. Rep. (BNA) 3277, 3282 (Aug. 6, 1980) (advising prosecutors, in cases involving man- 
concerns of opponents of the Sentencing Guidelines was that increased penalties would result in fewer prosecutions because the government would file charges only against the most serious offenders. While juries unay be concerned about the environmental welfare of this nation, they are likely to sympathize with individuals who will face jail sentences for crimes of which they had no actual knowledge. ${ }^{117}$ In fact, "it is often difficult for courts to impose jail sentences" on responsible corporate officers. ${ }^{118}$

Not only may juries be negatively affected, but prosecutors may be discouraged from bringing criminal charges against environmental violators if the penalties are too great. Given the high penalties of conviction, the government may decide to bring suit against only the inost flagrant violators. Thus responsible corporate officers of corporations who are guilty of lesser violations would have no incentive to atteinpt to prevent environmental violations.

The primary goal of criminal prosecutions of environmental crimes is deterrence, ${ }^{119}$ and the responsible corporate officer doctrine is an effective way of achieving that goal. Holding responsible corporate officers criminally liable for the actions of their companies is intended to encourage corporations to police the actions of their employees and to imitiate programs that will prevent environmental violations before they occur. ${ }^{120}$ One commentator has stated that the Guidelines inean that "environmental convictions are likely to have more serious consequences than in the past, further supporting the need for internal corporate controls to minimize the likelihood of violations altogether."121 Proponents of aggressive criminal prosecution of corporate officers advocate imposing the "sorts of penalties" that inake pin-striped decision-makers go pale." "122

datory minimum sentences, to consider that "unusually mitigating circumstances may make the specified penalty appear so out of proportion to the seriousness of the defendant's conduct that the jury or judge in assessing guilt . . . may be influenced by the inevitable consequence of conviction")

117. Miller et al., supra note 115 , at 414 .

118. Starr, supra note 106 , at 383 .

119. Id. at 382 .

120. Starr \& Kelly, supra note 1 , at 10,102 .

121. Andrew S. Hogeland, Criminal Enforcement of Environmental Laws, 75 MASs. L. REV. 112, 121 (1990).

122. Adler \& Lord, supra note 5, at 796 (quoting Mark Muro, What Punishment Fits a Corporate Crime?, Boston GloBE, May 7, 1989, at A1, A6). 
The deterrent action of this doctrine will not be compromised by allowing a downward departure from the Guidelines for a defendant convicted under a responsible corporate officer theory. A corporate officer ${ }^{123}$ will be deterred by the threat of any jail term, regardless of its length. ${ }^{124}$ It is unrealistic to think that a whitecollar professional will be less likely to try to prevent corporate violations of environmental statutes because the possible jail time is only 41 to 51 months, rather than 51 to 63 months. ${ }^{125}$ The true deterrent effect of the Guidelines lies in the elimination of suspended sentences and probation. The fact that most convicted violators will serve some time in prison is what a responsible corporate officer finds frightening; the length of the sentences is almost irrelevant. Thus, allowing a downward departure for responsible corporate officers will not decrease the deterrent effect of the doctrine, although discouraging prosecution and/or conviction with excessive prison terms will.

Although the courts have decided that public welfare dictates that corporate officers have knowledge imputed to them or inferred by the trier of fact from the surrounding circumstances, the defendant's relative culpability should still be considered in sentencing. ${ }^{126}$ As one commentator has noted, "[r]egardless of the extent of public need for protection from environmental harms, the judicial criminal process is not excused from an accurate assessment of culpability for convictions that may result in the loss of a defendant's liberty.", 127

A provision in the Guidelines that would allow a downward departure for conviction under the responsible corporate officer doctrine would help ensure that sentences are perceived as just

123. See Starr, supra note 106, at 383 (describing the typical defendant in these cases as "a 'successful' businessman, or otherwise prominent citizen without a prior criminal record or other public blemish").

124. Hare, supra note. 15 , at 975 n.267 (commenting that "[f]or corporate officers, thirty days in jail is likely to be a very long time")

125. These figures assume a conviction under $\S 2 \mathrm{Q} 1.1$ (entitled "Knowing Endangerment Resulting from Mishandling Hazardous or Toxic Substances, Pesticides or Other Pollutants"), which has a base offense level of 24 , and a two level decrease I suggest should be used for "responsible corporate officer" status. GUIDELINES MANUAL, supra note $8, \S 2 \mathrm{Q} 1.1$, at 280 .

126. Andrew von Hirsh, Desert and White Collar Criminality: A Response to Dr. Braithwaite, 73 J. CRIM. L. \& CRIMINOLOGY 1164, 1164-75 (1982) (arguing for "blameworthiness of criminal conduct as the proper determinant of the severity of punishments").

127. Hare, supra note 15 , at 978. 
and reasonable by the general public and prosecutors alike. This will encourage respect for, and faith in, the criminal justice system.

\section{CONCLUSION}

Public concern with environmental issues has resulted in increased criminal prosecutions of environmental violations, as well as increased penalties for those convicted of such crimes. The responsible corporate officer doctrine lias been an important and effective tool in these prosecutions. However, this doctrine lias not been adequately taken imto account in the Federal Sentencing Guidelines.

The government should continue to prosecute responsible corporate officers for the environmental violations of their compames, as prosecutions of this type have an especially strong deterrent effect. However, the Sentencing Guidelines should be amended to allow for downward departures in sentencing when the defendant is convicted under the responsible corporate officer doctrine. Downward departures would not decrease the deterrent effect of the doctrine but would ensure that juries will continue to convict corporate violators. Perliaps most importantly, it would take relative culpability imto account. Punishment commensurate to the crime is vital to our criminal justice system, and slould not be forgotten in the pumishment of environmental violators. 